\title{
Intention Model of Waste Management Education Concept Based on Green Campus in Brawijaya University
}

\author{
Sri Muljaningsih, Ajeng Kartika Galuh \\ Economics Department, Faculty of Economics and Business, Universitas Brawijaya, Malang, Indonesia
}

\begin{abstract}
This research was aimed to analyze the behaviors of Brawijaya University's stakeholders through the intention in managing waste. Considering that campus is a place of education, the analysis of the intention associated with the educational theory in cognitive, affective and psychomotor domains. Thus, this research implementation was supported by intention model. The objects of this research were the stakeholders of Brawijaya University consisting of students, lecturers, and staffs. This research was done using survey method with a total of 120 respondents. The analysis was conducted using a path analysis method with trimming. Given that the number of variables used was quite a lot, the data were first analyzed using a factor analysis method and then followed with a path analysis method. The results of the path analysis on Model 1 showed that the significant variables to the intention of managing waste were cognitive and behavioral control variables. The indicators of cognitive variable as knowing the types of waste and the economic benefits of waste. As for Model 2, the intention of managing waste significantly influenced the realization of the green campus varibles. The indicators of managing waste intention as intention to help manage waste in Brawijaya University, and then the indicators of green campus varible as the emerge of wise thoughts. As the suggestion, rules or policies on waste management are highly required to be established in Brawijaya University so that the stakeholders are willing to manage and process waste.
\end{abstract}

Keywords: Affective and psychomotor domains, Brawijaya University's stakeholders, Cognitive, Green campus, Waste management intention model

\section{INTRODUCTION}

The phenomenon of waste is a consequence of human activities. Every human activity must generate waste or garbage. The amount or volume of waste is proportional to the consumption levels of goods that people use daily. Similarly, the type of waste depends on the types of materials that people consume. Therefore, waste management cannot be separated from people's lifestyles. The increase in population and lifestyle profoundly affects the amount or volume of waste.

Law No.18 of 2008 on Waste Management and Government Regulation No.81 of 2012 have proposed the need for a fundamental paradigm shift in waste management from the old paradigm of collect - transform - dispose into a paradigm emphasizing on waste reduction and waste management. The waste reduction activities are intended for all community levels including the government, broader community, industries, and educational sector such as schools and universities to carry out waste restriction, recycling and reusing or better known as Reduce,

Correspondence address:

Sri Muljaningsih

Email : muljaningsih@ub.ac.id

Address : Economics Department, Faculty of Economics and Business, Universitas Brawijaya, Malang, Indonesia
Reuse, and Recycle (3R) paradigm through smart, efficient and programmatic efforts. However, the activities of $3 R$ still face a significant obstacle, which is the low awareness of the community to sort or classify waste.

Education or teaching can influence a person's skill and mental. According [1], education in all forms is to empower communities. In linear, education in Brawijaya University is also to empower the community or stakeholders of the campus. Therefore, education and teaching can improve students' self-confidence and capability. That is, education and teaching can develop the capacity of the campus's community and students to increase their self-awareness in protecting the environment, one of which is through waste management. According to [2], empowerment is: 1) to encourage motivation and increase awareness of one's potentials; 2) to give accessibility on opportunities for such empowerment; 3) to strengthen people of their inabilities by growing their self-reliance so that they can be independent. Thus, the empowerment of students and community of a campus can be done through development in the form of coaching and teaching. Furthermore, it is necessary to increase the socialization and education regarding waste management as 
effectively as possible. In achieving the empowerment of the Brawijaya University's stakeholders, public policies or rules are required holistically, established through infrastructural programs for the interests of the stakeholders. Additionally, innovative approaches and partnerships are conducted using dialogue among actors of the campus development [3].

The previous study explaining about waste management in Vermont University, with the organizing a waste sort and implementing an Eco-Reps Program based on the result could change waste disposal and purchasing habits of students on campus [4]. Waste management in Brawijaya University has not been done comprehensively. It is based on the fact that the waste processing is still limited to compost organic waste. In another side, non-organic waste is still not managed although the Study Program of Urban Planning has established a Waste Bank to accommodate non-organic waste and also has made cooperation with Malang Waste Bank (MWB). Waste has an economic value if appropriately managed. The waste saved on MWB can be converted into money. However, it turns out that not all stakeholders of Brawijaya University are interested in becoming a member of MWB. Therefore, to manage waste, education is highly required to make people aware of environmental preservation. In fact, the lesson materials of learning and teaching activities addressed to the students have been concerning the environmental preservation. However, education is not only about the cognitive domain, but also affective and psychomotor domains. Because to manage waste in campus not only the cognitive domain. So the students have to attitude behavior and skill implication. This research is importance. Thus, the objectives of this research is to analyze the behaviors of Brawijaya University's stakeholders on intention waste management to realize green campus.

\section{MATERIAL AND METHOD}

This research was done using survey method. The samples were determined using purposive sampling, covering the staffs, lecturers, and students. The total samples or respondents were 120 people, consisting of 62 students, 28 staffs, and 30 lecturers. The data were collected purposive sampling. Research instruments are tools used in data collection. The data collection in this research was conducted using open and structured interview method through a questionnaire. A factor analysis was used to determine the dominant variable, and a path analysis was performed to find out the relationship between the dependent and independent. It is described in detail as follows:

\section{a. Factor Analysis Cognitive Variable}

The factor analysis results of the cognitive variable consisting of 9 (nine) indicators (K1-K9) fulfilled the requirement with the MSA value of 0.820 and a significant result(0.000) of Bartlett of sphericity test. The factor calculation results with a rotation method on the 9 (nine) indicators were summarized into 2 (two) factors as presented in Table 1. Each factor consists of a combination of indicators that have the highest value between them (in bold).

\begin{tabular}{lcc} 
Table 1. Factor Weight of Cognitive Variable & \multicolumn{2}{c}{ Factors } \\
\hline Indicators of Cognitive Domain : & $\mathbf{1}$ & $\mathbf{2}$ \\
\hline & 0.075 & $\mathbf{0 . 8 4 2}$ \\
& 0.124 & $\mathbf{0 . 6 8 3}$ \\
K1. Knowing the types of waste & 0.354 & $\mathbf{0 . 7 3 4}$ \\
K3. Knowing the sources of waste generation & 0.443 & $\mathbf{0 . 5 9 6}$ \\
K4. Knowing how to sort waste & $\mathbf{0 . 6 9 5}$ & 0.341 \\
K5. Knowing the problems of environmental & & \\
damage & $\mathbf{0 . 6 9 2}$ & 0.346 \\
K6. Knowing how to preserve the environment & $\mathbf{0 . 7 6 5}$ & 0.088 \\
K7. Knowing the ecological benefits of waste & $\mathbf{0 . 8 0 7}$ & 0.116 \\
K8. Knowing the economic benefits of waste & $\mathbf{0 . 7 6 6}$ & 0.217 \\
\hline K9. Knowing the social benefits of waste & &
\end{tabular}

Source: Computational results

Table 2. Factor Weight of Psychomotor Variable

\begin{tabular}{lc}
\hline Indicators of Psychomotoric/Skill Domain : & Factor \\
\hline P1. Ease of disposing of waste in the right place & $\mathbf{1}$ \\
P2. Ease of sorting waste & 0.642 \\
P3. Ease of making compost & 0.693 \\
P4. Ease of making recycled craft & $\mathbf{0 . 7 6 6}$ \\
P5. Ease of utilizing used goods & $\mathbf{0 . 8 1 4}$ \\
P6. Ease of minimizing the use of goods that will be wasted & $\mathbf{0 . 8 2 7}$ \\
Source: Computational results & 0.686 \\
\hline
\end{tabular}

\section{Psychomotor Variable}

The factor analysis result of the psychomotor variable consisting of 6 (six) indicators (P1-P6) fulfilled the requirement with the MSA value of 0.762 and a significant result(0.000) of Bartlett of sphericity test. The factor calculation results with a rotation method on the 6 (six) indicators were summarized into 1 (one) factor as presented in Table 2. The indicator dominating this formed factor is indicated by the highest weight (in bold).

\section{Affective Variable}

The factor analysis results of the affective variable consisting of 16 (sixteen) indicators 
Table 3. Factor Weight of Affective Variable

\begin{tabular}{|c|c|c|c|c|}
\hline \multirow{2}{*}{ Indicators of Affective/Conation Dimension: } & \multicolumn{4}{|c|}{ Factors } \\
\hline & 1 & 2 & 3 & 4 \\
\hline A1. Willingness to dispose of waste in the right place & 0.004 & 0.177 & 0.019 & 0.705 \\
\hline A2. Willingness to sort waste & 0.391 & 0.023 & 0.253 & 0.633 \\
\hline A4. Like to utilize used newspaper to wrap goods & 0.091 & 0.036 & 0.794 & 0.179 \\
\hline A5. Like to use cloth bags for shopping & 0.252 & 0.006 & 0.771 & 0.192 \\
\hline A8. Like to make creations recycled from used goods & 0.466 & 0.375 & 0.418 & -0.311 \\
\hline A9. Willingness to socialize the benefits of waste & 0.801 & 0.182 & 0.177 & 0.044 \\
\hline A10. Spirit to do activities of loving the environment & 0.644 & 0.421 & 0.040 & 0.010 \\
\hline A11. Optimism that waste can have economic added value if managed well & 0.620 & 0.007 & -0.009 & 0.397 \\
\hline A12. Ability to organize waste care institutions & 0.731 & -0.049 & 0.247 & 0.065 \\
\hline
\end{tabular}

Source: Computational results

Table 4. Factor Weight of Subjective Norm Variable

\begin{tabular}{|c|c|c|}
\hline \multirow{2}{*}{ Indicators of Subjective Norm Variable } & \multicolumn{2}{|c|}{ Factors } \\
\hline & 1 & 2 \\
\hline NS1. Interests to improve Brawijaya University's environment & 0.420 & 0.562 \\
\hline NS2. Authorities to get involved in Brawijaya University's environmental improvement & 0.848 & 0.082 \\
\hline NS3. Waste management regulations in Brawijaya University & 0.830 & 0.240 \\
\hline NS4. Sanction determination for environmental destruction in Brawijaya University & 0.804 & 0.249 \\
\hline NS5. Needs of Brawijaya University's Waste Bank institution establishment & 0.144 & 0.771 \\
\hline
\end{tabular}

Source: Computational Results

(A1-A16) fulfilled the requirement with the MSA value of 0.834 and a significant result(0.000) of Bartlett of sphericity test. The factor calculation results with a rotation method on the 16 (sixteen) indicators were summarized into 4 (four) factors as presented in Table 3. Each factor consists of a combination of indicators that have the highest weight among them (in bold).

\section{Subjective Norm Variable}

The factor analysis results of the subjective norm variable consisting of 6 (six) indicators (NS1-NS6) fulfilled the requirement with the MSA value of 0.775 and a significant result(0.000) of Bartlett of sphericity test.The factor calculation results with a rotation method on the 6 (six) indicators were summarized into 2 (two) factors as shown Table 4. Each factor consists of a combination of indicators that have the highest weight between them (in bold).

\section{Behavioral Control Variable}

The factor analysis results of the behavioral control variable consisting of 4 (four) indicators (KP1-KP4) fulfilled the requirement with the MSA value of 0.707 and a significant result(0.000) of Bartlett of sphericity test. The factor calculation results with a rotation method on the 4 (four) indicators were summarized into 1 (one) factor as presented in Table 5. The indicator dominating the formed factor is indicated by the highest weight (in bold).

\begin{tabular}{lc} 
Table 5. Factor Weight of Behavioral Control Variable & \\
\hline Indicators of Perceived Behavioral Control & Factor \\
\hline $\begin{array}{l}\text { KP1. Willingness to learn about how to process waste } \\
\text { KP2.Willingness to be actively involved in managing }\end{array}$ & 0.732 \\
waste in Brawijaya Univesity & $\mathbf{0 . 8 0 2}$ \\
KP3. Capability or readiness to sort the self-owned & 0.696 \\
$\begin{array}{l}\text { waste } \\
\text { KP4. Efforts to maintain environmental sustainability }\end{array}$ & $\mathbf{0 . 7 9 2}$ \\
in Brawijaya University &
\end{tabular}

Source: Computational Results

\section{Waste Management Intention Variable}

The factor analysis results of the waste management intention variable consisting of 3 (three) indicators (N1-N3) fulfilled the requirement with the MSA value of 0.693 and a significant result(0.000) of Bartlett of sphericity test. The factor calculation results with a rotation method on the 3 (three) indicators were summarized into 1 (one) factor as presented in Table 6 . The indicator dominating the formed factor is indicated by the highest weight (in bold). 
Table 6. Factor Weight of Waste Management Intention Variable

\begin{tabular}{lc}
\hline Indicators of Behavioral Intention & Factor \\
\hline $\begin{array}{l}\text { N1. Planning to be involved in Brawijaya } \\
\text { University's waste management }\end{array}$ & 0.899 \\
$\begin{array}{l}\text { N2. Intention to help manage waste in } \\
\text { Brawijaya University }\end{array}$ & 0.901 \\
$\begin{array}{l}\text { N3. Intention to be a customer of Brawijaya } \\
\text { University's Waste Bank }\end{array}$ & 0.809 \\
\hline
\end{tabular}

Source: Computational Results

\section{Green Campus Variable}

The factor analysis results of the green campus variable consisting of 4 (four) indicators (PGC1PGC4) fulfilled the requirement with the MSA value of 0.781 and a significant result(0.000) of Bartlett of sphericity test.The factor calculation results with a rotation method on the 4 (four) indicators were summarized into 1 (one) factor as presented in Table 7. The indicator dominating the formed factor is indicated by the highest weight (in bold).

Table 7. Factor Weight of Green Campus Variable

\begin{tabular}{lc}
\hline Indicators of Green Campus Variable & Factor \\
& $\mathbf{1}$ \\
\hline PGC1.Paradigm change of waste & 0.782 \\
PGC2. The emerge of wise thoughts & $\mathbf{0 . 8 4 8}$ \\
PGC3. The establishment of waste management & 0.818 \\
$\begin{array}{l}\text { institutions } \\
\text { PGC4. The establishment of greenor } \\
\text { environment-based curriculum }\end{array}$ & $\mathbf{0 . 8 3 0}$ \\
\hline
\end{tabular}

Source: Computational Results
Path analysis is an extension of regression analysis that can involve more than one relationship model to form Simultaneous Equation System (SES). Path analysis can be applied to SES when the relationship between response variables moves in one direction (causal). The use of path analysis is not to form a model based on explanatory variables that significantly affect the response variables but to examine the model of the relationship between variables in the model that has been formulated by the researcher based on existing theories [12].

Path analysis was applied in this research to determine the correlation between the behavioral intention of Brawijaya University's stakeholders to manage waste and the attitudes: cognitive, psychomotor and affective, behavioral control, subjective norms in realizing the concept of green campus in Brawijaya University.

Before doing path analysis, a diagram called as path diagram must first be formed. Path diagram is a graphic form of the overall relationship that exists in a model construction. Path diagram was designed based on the general (theoretical) knowledge by considering the basis of the causal relationship between variables and considerations of previous research or basic estimations to facilitate path analysis [2]. The path diagram used in this research is shown in Figure 1.

\section{b. Path Analysis}

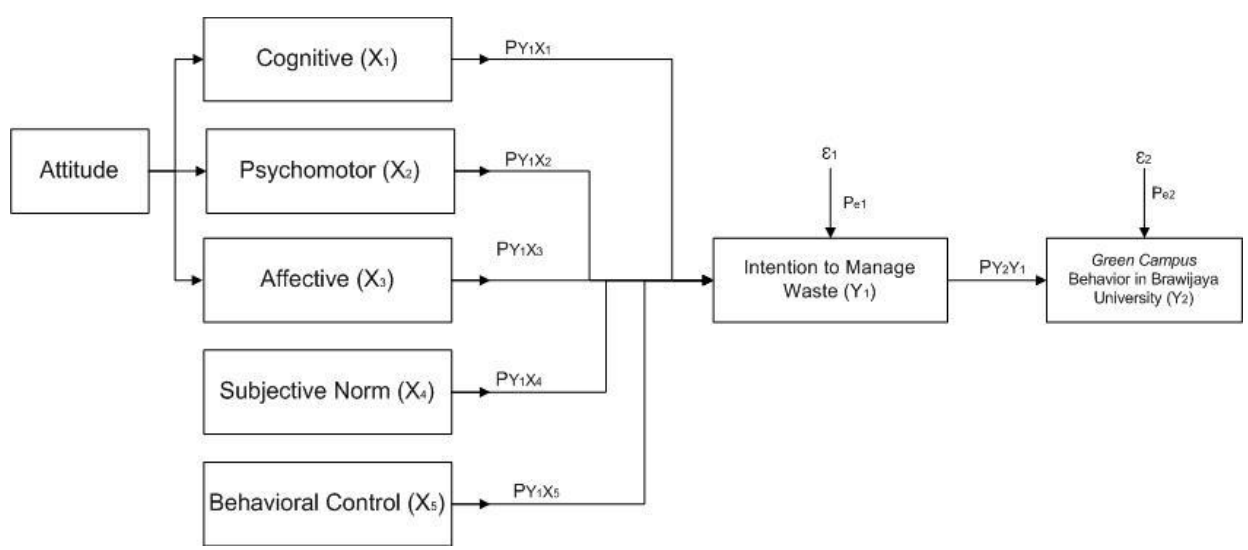

Figure 1. Resear Fch Path Diagram

The regression equation or structural model for the path diagram is as follows:

1.Intention to manage waste $=$

$P_{Y 1 X 1}$ cognitive $+P_{Y 1 X 2}$ psychomotor $+P_{Y 1 X 3}$ Affective $+P_{Y 1 X 4}$ Subjective Norm $+P_{Y 1 X 5}$ Behavioral Control $+\varepsilon_{1}$

2.Green campus Behavior=

$P_{Y 2 Y 1}$ Interest/Intention to Manage Waste $+\varepsilon_{2}$ 


\section{RESULT AND DISCUSSION}

The analysis of the behaviors of Brawijaya University's stakeholders was based on the Theory of Planned Behavior (TPB) related to psychological elements and supported by the concept of entrepreneurship [5]. The thought establishment of the intention or interest in managing the Waste Bank of Brawijaya University referred to a research conducted [6] on the structural relationship between attitudes toward environmental activities, subjective norms, and perceived behavioral controls, as well as the students' intention to engage in environmental management and green campus initiatives. The concept model proposed [5] is similar to the classic entrepreneurial intention model adopted [6]. Furthermore, the intention or interest towards entrepreneurial goals based on opportunity evaluation can be formed. The entrepreneurial goals are built from the integration of cognitive elements of the entrepreneur. The cognitive elements are inseparable from the aspects of education and training [7].

Education is a process aimed at changing learners or students. Therefore, education or training programs are expected to make significant changes to the participants of education and training. This thinking is according to research conducted [8] on the significance of education as a process of change. Besides, the process of education is influenced by various experiences. However, the principle of the educational process is expected to make learners or students able to develop cognitive, affective and psychomotor characteristics. In the cognitive domain, there are six (6) levels covering the lowest to the highest educational process level. These six levels consist of knowing (knowledge), understanding, applying, analyzing, synthesizing and evaluating. The terms of the taxonomy levels have improved into remembering, understanding, and applying, analyzing, evaluating and creating (creation). As for the psychomotor domain, there are five (5) levels hierarchically consisting of imitation, manipulation, precision, articulation, and naturalization. The point of naturalization is that the movement occurs spontaneously or without rethinking. In another side, the affective domain is related to the points starting with the emotion or feeling. This taxonomy describes a person's process of accepting a value. The result shapes attitudes, which become the guide in behaving. In the affective domain, there are five (5) levels consisting of receiving, responding, valuing, organization, and characterization.

One of green campus ideas shows the relationship between ecology and neoclassical economics. According to [9], neoclassical economics and ecology are influenced by human actions. A utilitarian study has several moral philosophies, stating that in working, there should be a balance between pleasure and pain. All creatures affected, both who feel pain and pleasure must be accounted. If this argument is accepted, prosperity will depend on the utility of all 'living' creatures, not only on individual utility. Normative economics does not take non-human utility into account. It is the effect of an anthropocentric act in which what is taken into consideration from non-human creature is only limited to what extent it can result in pain or pleasure for humans. If no human is (mentally) ill due to the suffering caused by the state of animals, then suffering is not the measure of pleasure or pain that can be used to judge actions. That is, not every human feels pain due to animal suffering or damage to other goods such as buildings. However, if humans feel pain due to the condition, then the evaluation of actions resulted from the accident and suffering should be taken into consideration.

In principle, intentions have a high correlation with behaviors. Thus, intentions can be used to plan behaviors. The significance of attitudes is affective. Determination of one's attitude is based on the representation of knowledge possessed on an object.

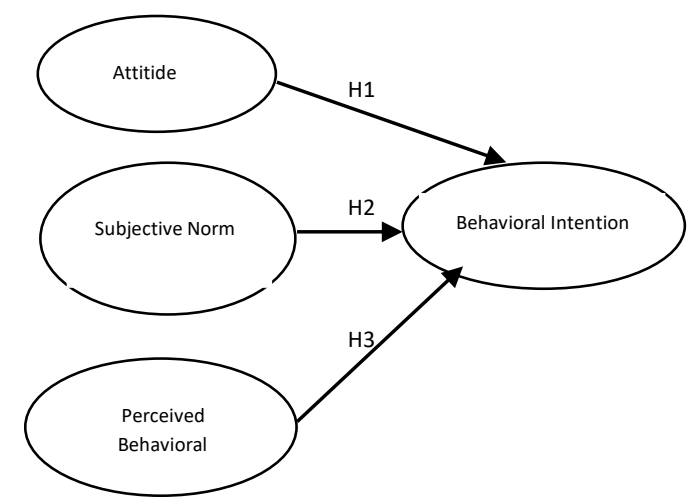

Figure 2. Model Framework for Building Hypotheses

Description:

$\mathrm{H} 1=$ Attitude positively influences the behavioral intention of Brawijaya University's stakeholders to engage in 
environmental activities and green campus initiatives.

$\mathrm{H} 2=$ Subjective norm positively influences the behavioral intention of Brawijaya University's stakeholders to engage in environmental activities and green campus initiatives.

$\mathrm{H} 3=$ Perceived behavioral control positively influences the behavioral intention of Brawijaya University's stakeholders to engage in environmental activities and green campus initiatives.

The meaning of subjective norms is a person's belief in the approval of the competent party (trusted) to take actions. That is, the trusted party is the motivator. The meaning of perceived ease or difficulty to take actions is based on the belief affecting one's intentions. The research model framework to build hypothesesis shown in Figure 2.

Before answering the statements of problems of this research, the researchers first tested the validity and reliability of the questionnaire. The results of the test were valid and reliable based on the calculation of Cronbach's Alpha value resulting in 0.939 . Furthermore, to answer the first problem statement (determining the dominant variable), a factor analysis was used. Meanwhile, to answer the second problem statement, a path analysis was conducted. The results and discussion are outlined as follows.

\section{Path Analysis Results and Discussion}

The results of the path analysis were first outlined in the form of path diagram as presented in Figure 3.

The assumption of path analysis that needed to be tested statistically was the linearity assumption of the relationship between variables. Here are the results of the linearity assumption test.

\section{Model 1}

For model 1, the linearity assumption was tested on the relationship between the cognitive, affective, psychomotor, subjective norm, behavioral control and the intention to manage waste. The summary of the linearity test is presented in Table 8.
Table 8. Model 1- Linearity Test Results

\begin{tabular}{llll}
\hline $\begin{array}{l}\text { Dependent } \\
\text { Variable }\end{array}$ & $\begin{array}{l}\text { Independent } \\
\text { Variable }\end{array}$ & F & Sig. / P \\
\hline Waste & Cognitive & 21.277 & $0.000^{* *}$ \\
Management & Affective & 18.794 & $0.000^{* *}$ \\
Intention & $\begin{array}{l}\text { Psychomotor } \\
\text { Subjective }\end{array}$ & 18.114 & $0.000^{* *}$ \\
& Norm & & $0.000^{* *}$ \\
& Behavioral & 86.612 & $0.000^{* *}$ \\
& Control & &
\end{tabular}

Note: $n s=$ not significant; $*$ significant at $\alpha=10 \%$; ${ }^{*}=$ significant at $\alpha=5 \%$

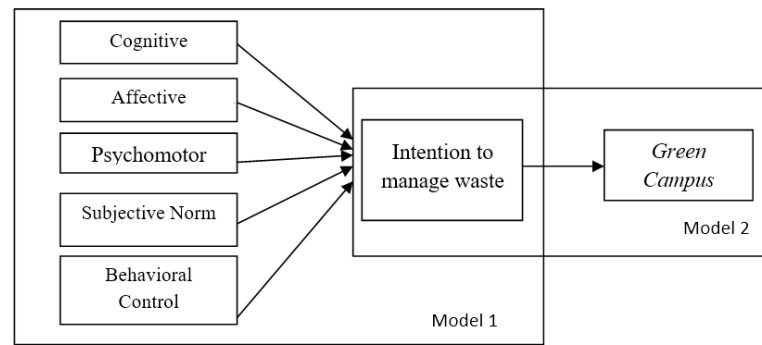

Figure 3. Initial Path Diagram

Based on Table 1, the linear relationship between the cognitive, affective, psychomotor, subjective norm, behavioral control and the intention to manage waste was significant at $\alpha=5 \%$. Thus, it was indicated that all independent variables in Model 1 met the linearity assumption and deserved to be included in the next path analysis.

\section{Model 2}

In model 2, the relationship of which the linearity needed to be tested was the relationship between the waste management intention and green campus as shown in Table 9.

Based on Table 9, it can be seen that the linear relationship between the waste management intention and the green campus was significant at $\alpha=5 \%$. Thus, it was indicated that the waste management intention variable met the linearity assumption.

Table 9. Model 2-Linearity Test Result

\begin{tabular}{llcc}
\hline $\begin{array}{l}\text { Dependent } \\
\text { Variable }\end{array}$ & $\begin{array}{l}\text { Independent } \\
\text { Variable }\end{array}$ & F & Sig. / P \\
\hline $\begin{array}{l}\text { Green } \\
\text { campus }\end{array}$ & $\begin{array}{l}\text { Waste } \\
\text { management } \\
\text { intention }\end{array}$ & 23.706 & $0.000^{* *}$ \\
\hline $\begin{array}{l}\text { Note: } n s= \\
\text { not significant; }\end{array}{ }^{*}=$ significant at \\
$\alpha=10 \% ; * *$ significant at $\alpha=5 \%$
\end{tabular}


The Intention of Stakeholders Brawijaya University to Manage Waste (Muljaningsih, et al.)

Table 10. Results of Path Coefficient Estimation Using Standardized Regression Coefficients (Beta)

\begin{tabular}{cllccc}
\hline Model & \multicolumn{1}{c}{$\begin{array}{c}\text { Dependent } \\
\text { Variable }\end{array}$} & \multicolumn{1}{c}{ Independent Variable } & Beta & T & Sig. / P \\
\hline Model 1 & Waste management & Cognitive & 0.180 & 2.213 & $0.029^{* *}$ \\
& intention & Affective & 0.010 & 0.116 & $0.908^{\text {ns }}$ \\
& & Psychomotor & -0.023 & -0.245 & $0.807^{\text {ns }}$ \\
& & Subjective norm & 0.041 & 0.463 & $0.644^{\text {ns }}$ \\
Model 2 & Green campus & Behavioral control & 0.573 & 6.602 & $0.000^{* *}$ \\
\hline
\end{tabular}

Note: $n s=$ not significant; ${ }^{*}=$ significant at $\alpha=10 \% ;{ }^{* *}=$ significant at $\alpha=5 \%$

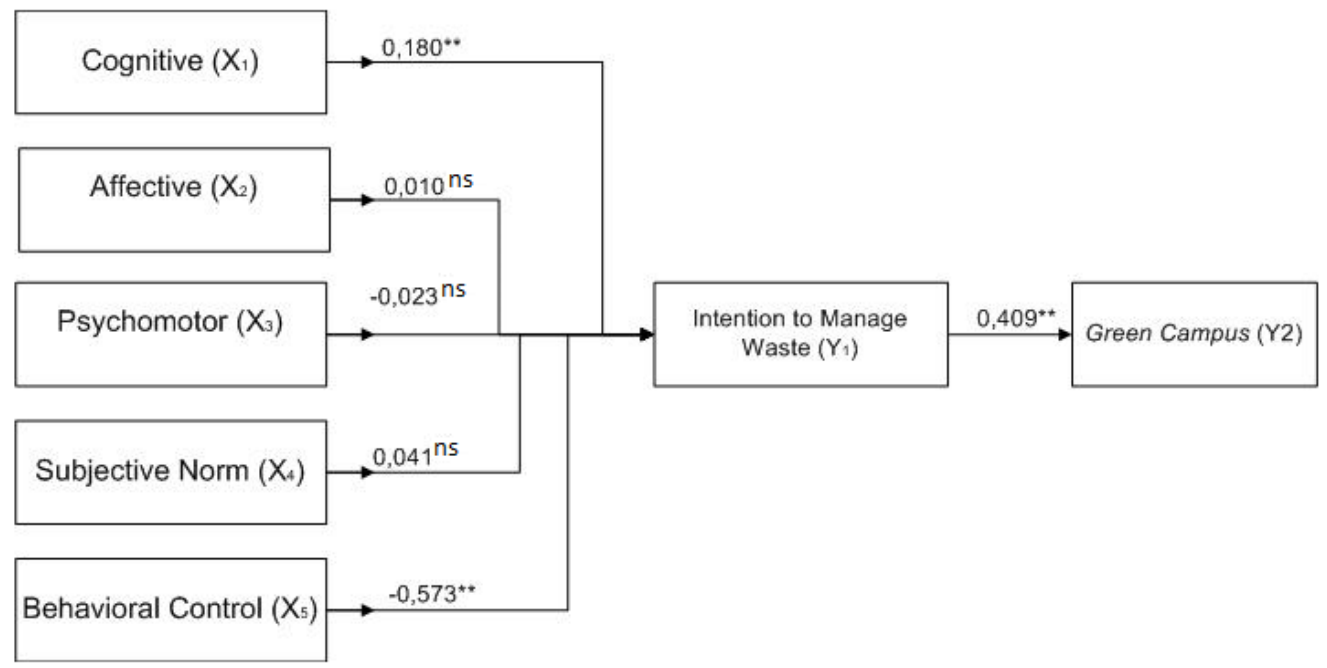

Figure 4. Correlation Results on Path Diagram

Here is the equation of mathematical estimation model based on the standardized regression coefficients:

$$
\begin{aligned}
& Z \widehat{Y}_{1}=0.180 Z X_{1}+0.010 Z X_{2}-0.023 Z X_{3}+0.041 Z X_{4}+0.573 Z X_{5} \\
& Z \widehat{Y}_{2}=0.409 Z Y_{1}
\end{aligned}
$$

Table 10. Results of Path Coefficient Estimation Using Standardized Regression Coefficients (Beta) After Trimming

\begin{tabular}{lllccc}
\hline Model & Dependent Variable & Independent Variable & Beta & T & Sig. / P \\
\hline \multirow{2}{*}{ Model 1 } & Waste management & Cognitive & 0.179 & 2.442 & $0.016^{* *}$ \\
\cline { 2 - 2 } & intention & Gehavioral control & 0.586 & 7.978 & $0.000^{* *}$ \\
\hline
\end{tabular}

Note: $n s=$ not significant; ${ }^{*}=$ significant at $\alpha=10 \% ;{ }^{* *}=$ significant at $\alpha=5 \%$

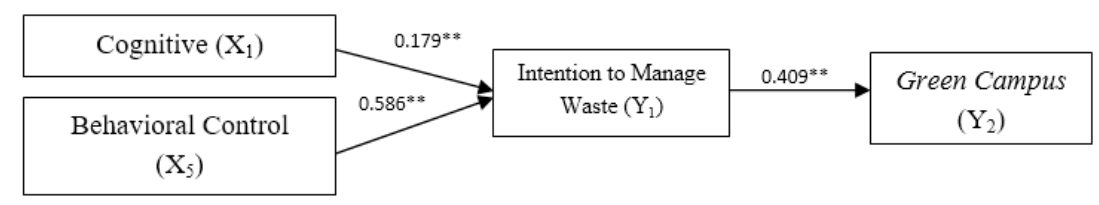

Figure 5. Path Diagram after Trimming

The new mathematical estimation model obtained is as follows:

$Z \widehat{Y}_{1}=0.179 Z X_{1}+0.586 Z X_{5}$
$Z \widehat{Y}_{2}=0.409 Z Y_{1}$ 
The next stage of the path analysis was estimating the path coefficients using standardized regression coefficients. The results of the path coefficient estimation were presented in Table 10.

Furthermore, a diagram was made to describe the correlation between the variables in Model 1 and Model 2. For Model 1, the variables that were significant to the waste management intention consisted of cognitive variable and behavioral control variable. Meanwhile, in Model 2 , the concept of the green campus was affected by the waste management intention. The diagram is shown in Figure 4.

In this research, the equation (1) can be interpreted as follows:

a. Any increase of 1 (one) standard unit of cognitive characteristics would increase the waste management intention by 0.180 unit, assuming other variables were constant. In other words, the influence of cognitive characteristics on the waste management intention was positive.

b. Any increase of 1 (one) standard unit of affective characteristics would increase the waste management intention by 0.010 standard unit, assuming other variables were constant. In other words, the influence of affective characteristics on the waste management intention was positive.

c. Any increase of 1 (one) standard unit of psychomotor characteristics would reduce the waste management intention by 0.023 standard unit, assuming other variables were constant. In other words, the influence of psychomotor characteristics on the waste management intention was negative.

d. Any increase of 1 (one) standard unit of the subjective norm would increase the waste management intention by 0.041 standard unit, assuming other variables were constant. In other words, the influence of subjective norm on the waste management intention was positive.

e. Any increase of 1 (one) standard unit of behavioral control would increase the waste management intention by 0.573 standard unit, assuming other variables were constant. In other words, the influence of behavioral control on the waste management intention was positive.

However, of the five independent variables, there were only two variables that significantly influenced the intention to manage waste covering cognitive variable and behavioral control variable. Meanwhile, the equation (2) can be interpreted that an increase of 1 (one) standard unit of waste management intention would developthe concept of green campus by 0.0409 standard unit and the influence was significant.

Because there was an insignificant influence of independent variable, trimming was conducted to eliminate the insignificant path. Thus, it was obtained the results of the new path coefficient estimation after the trimming as presented in Table 4.

In the end, it was obtained the depiction of the condition after trimming as shown in Figure 5.

Based on the results of the regression analysis after trimming, all the independent paths or variables were significant. Thus, the path diagram after trimming was the final path diagram in this research.

The information obtained is that cognitive characteristics directly influenced waste management intention of 0.179 standard unit while behavioral control directly influences waste management intention of 0.586 standard unit. In another side, the direct influence of waste management intention on the green campus was 0.409 standard unit. In another side, the indirect influence of cognitive characteristics on the green campus through the intention to manage waste could be obtained from the results of the multiplication between the cognitive path coefficients towards waste management and the waste management path coefficients towards green campus, which was $0.179 \times 0.409=0.073$ standard unit. Meanwhile, the indirect influence of behavioral control on the green campus was $0.586 \times 0.409=0.240$ standard unit. Thus, the green campus improvement can be realized by increasing the intention to manage waste supported by cognitive and behavioral control.

This research is almost similar to that of School Children, High School and Higher Secondary Schools in Kerala India, concerning awareness, attitude and practice of School Students towards household waste management [15]. But the analysis tool used is t-test, the result shows a significant difference between awareness and practice. In fact there is a gap between knowledge and practical. Similarly, understanding and advancing campus sustainability using a systems framework, study at Vermont University in USA [4]. The result is to accelerate the sustainability of the campus by way of commitment to the campus organization wisely and continuous improvement of 
environmental and social conditions that provide institutional benefits. Therefore required a system capable of making major changes to overcome complex problems in Universities. While the green campus program at Portland State University by reviewing the level of student knowledge and practices associated with green campus [16]. The results of this study indicate that the green campus strategy by improving the main student knowledge, but more important is to apply in life in a sustainable manner. The attitude of students to care for the higher green campus who have knowledge of green campus than those who do not. Therefore, it would be important to focus more on green campus projects. Further development of green campus in China with example campus energy management. With these great endeavors, an upgrade from the energy and resources of campus is on progress, which expands its scope to sustainable education and the initiative of low carbon life on campus [17]. Meanwhile, to reduce the use of energy on campus which is significant is environmental awareness and personal motivation [18]. Then research on traditional and experimental ways of learning. The experimental method in student groups applying the curriculum of learning innovation to environmental education on sustainable development shows more exposed [19]. The test equipment in the experimental research is the level of environmental knowledge, attitude, skills and behavior on water, biodiversity conservation and solid waste management. It is apparent in the study of "Stdents' attitudes to solid waste management in a Nigerian university: Implications for campus-based sustainability education" [20]. The results show that although the problem was widespread, only 40.5 per cent of the students expressed serious concerns for solid waste practices. Also, while the students were positively disposed to innovation, there were significant differences in students' awareness and disposition according to sex, age, academic level and faculties. Furthermore, to realize the green campus by first doing: 1) a review of current Campus Suatainability Assessments (CSAs); 2) CSAs performing and comparing the results obtained from two internationally recognized (ie, Green Metric and ISCN); 3) proposing a new CSA approach that encompasses clusters of homogeneous campus typologies for meaningful comparisons and university rankings [21].
Based on the study of various other studies, that the study of green campus Brawijaya University especially on waste management by reviewing the interest of stakeholders to care about the waste in order to realize the cleanliness of the campus environment in a sustainable manner. All studies related to education to manage waste and to the green campus by reviewing the cognitive, affective and psychomotor/skills. The result of the discussion of the study, then to increase the interest of stakeholder Brawijaya University is not only to see cognitive and behavioral control, but to give real practice or application in realizing green campus especially on waste management. Whereas in campus of Brawijaya there is already composting unit, embryo of garbage bank, but management has not been thoroughly to all existing waste.

This study is a respondent is a stakeholder consisting of students, lecturers and administrative staff. While other research respondents are students. It is basically the majority campus filled by students. But for the green campus program involving stakeholders in an integrated manner.

\section{CONCLUSIONS AND SUGGESTION Conclusions}

Based on the results of this research, it is concluded that the significant variables on the intention to manage waste in Brawijaya University are attitude and behavioral intention variables while the subjective norm variable is not significant. In another side, the attitudes in cognitive domain are still at the level of understanding or theoretical knowledge while the perceived behavioral control is the existence of willingness to manage waste, which drives the intention or interest to manage waste. Unfortunately, the real action has not been realized. It is in line with the insignificant subjective norm, indicating that there has not been any real rule regarding the condition of waste management in Brawijaya University environment. Nevertheless, the stakeholders are willing or interested in realizing the green campus concept of Brawijaya University.

\section{Suggestion}

Based on the conclusion of this research, it is suggested that in the future, Brawijaya University establish rules or norms related to waste management to realize the green campus concept in Brawijaya University. Additionally, it is expected that Brawijaya University can design a 
practical learning of waste management to the students and other stakeholders that eventually can foster their attitudes of the affective domain or familiarize them to more care of waste.

\section{ACKNOWLEDGMENT}

This research is funded from the budget allocated for the green campus program of Brawijaya University. Therefore, the researchers gratefully acknowledge the help provided by the Rector and Vice Rector IV along with the expert staffs. Furthermore, the researchers would like to thank the colleagues who helped the implementation of this research.

\section{REFERENCES}

[1]. Acker,D. \& Gasperini, L. (2009). Education for Rural People. The Role of Education Training and Capacity Development in Poverty Reduction and Food Security. FAO (Food and Agriculture Organization of The United Nation). Rome, Italy. p.iii-iv.

[2]. Elizabeth,R.(2007). Pemberdayaan Wanita Mendukung Strategi Gender Mainstreming dalam Kebijakan Pembangunan Pertanian di Perdesaan. Forum Penelitian Agro Ekonomi, Volume 25 No 2 December 2007: 128 -135.

[3]. OECD.(2012). Women's Economic Empowerment. The OECD DAC Network on Gender Equality (Gendernet). Promoting Pro-Poor Growth The Role of Empowerment -@ OECD 2012, p.1-4.

[4]. Posner,Stephen M, \& Stuart,Ralph.(2013). Understanding and advancing campus sustainability using a systems framework. International Journal os Sustainability I Higher Education Vol 14.No 3,2013. Pp 264277. Emerald Group Publishing Limited.

[5]. Ajzen,I. \& Fishbein, M.(1980). Understanding Attitude And Predicting Social Behavior. Englewood-Cliffs, NJ: Prentice-Hall. p.5-8; p.79-84.

[6]. Suki, N.M.\& Norbayah, M.S.(2015). Students Intention to Engage in Campus Environmental Activities and Green Initiatives: A Structural Equation Modelling Approach.2nd Regional Conference on Campus Sustainability: Capacity Building in Enhancing Campus Sustainability.Universiti Malaysia Sabah.

[7]. Elving. Jennie .(2009). Contextualizing Entrepreneurial Intention. Abo: Abo Akademi Press.
[8]. Kamil,M. 2010. Model Pendidikan dan Pelatihan (Konsep dan Aplikasi). Bandung: Alfabeta.

[9]. Bloom,B.S., Hastings, J.T.,\& Madaus, G.F. (1971). Handbook on Formative and Summative Evaluation of Student Learning. NY: McGraw-Hill, Inc.

[10]. Ajzen,I. \& Fishbein, M. (2005). The Influence of Attitudes on Behavior. In Albarracin D, Johnson B, Zanna M (eds.) The Handbook of Attitude. Lawrence Erlbaum Associates, Mahwah, pp. 173-221.

[11]. Supranto. 2004. Analisis Multivariat, Arti dan Interpretasi. Jakarta: Rineka Cipta.

[12]. Ghozali,I.2011. Aplikasi Analisis Multivariate dengan Program IBM SPSS 20, Edisi 6. Semarang: Penerbit Universitas Diponegoro.

[13]. Wright,S.1960. Path Coeficient and Path Regression: Alternative or Complementary Concepts. Journal of the Biometrics Society,Vol.16, No. 14, pp. 189-202.

[14]. Hair,J.F.,Anderson,R.E.,Tatham,R.L., \& Black, W.C.2009. Multivariate Data Analysis. NJ: Prentice $\mathrm{Ha} 2$

[15]. Licy.C.D;Vivek,Raghavan;Saritha,Kamath;Ani e, T.K ;Josphina,C.T. 2013. Awarness,Attitude and Practice of School Student toward Household Waste Management. Journal of Environment (2013),Vol.02, Issue 06,pp.147-150.

[16]. Choi,Yoon Jung ; Oh,Minjung ; Kang,Jihye and Lutzenhiser, Loren. 2017. Plans and Living Practices for the Green Campus of Portland State University Sustainability 2017, 9, 252

[17]. Tan,Hongwei; Chen,Shuqin; Shi,Qian; Wang,Lingling. 2014. Development of green campus in China. Journal of Cleanar Production 64 (2014) 646-653. Journal homepage: $\quad$ www.elsevier.com/locate/ jclepro

[18]. Wu, Andrew; Singh,Jaaved; Tikasz,Peter. 2013. Independent Study on Changing Student Behavior to Increase Energy Sustainability and Efficiency at the Macdonald Campus of McGill University. The Journal of Sustainable Development.Vol. 10,Idd.1 (2013),Pp.154179.

[19]. Alexandar.R, \& Poyyamoli G. 2014. The affeciveness of environmental education for sustainable development based on active teaching and learning at high school levelacase study from Puducherry and Cuddalore 
regions, India. Journal of Sustainability Education. Vol.7,December 2014.

[20]. Ifegbesan,Ayodeji Peter. 2017. Students' attitudes to solid waste management in a Nigerian university : Implications for campus-based sustainability education.International Journal of Sustainability Higher Education. Volume 18.Issue 7. Emerald Publishing Lilmited.

[21]. Sonetti, Giulia ; Lombardi ,Patrizia and Chelleri ,Lorenzo. 2016. True Green and Sustainable University Campuses? Toward a Clusters Approach. Sustainability 2016, 8, 83; doi:10.3390/su8010083 www.mdpi.com/journal/sustainability 